\title{
Assessment of viability in the bacterial standing stock of the Antarctic sea from the Indian side
}

\author{
Ponnapakam A. LOKA BHARATHI*, Shanta NAIR, Maria-Judith B.D. DE SOUZA, \\ Dorairajsingham CHANDRAMOHAN
}

Biological Oceanography Division, National Institute of Oceanography, Dona Paula, Goa 403-004, India

Received 22 May 2001; revised and accepted 23 August 2001

\begin{abstract}
During the austral summer, we examined the bacterial population along the cruise track extending from $70^{\circ} \mathrm{S}$ and $18^{\circ} \mathrm{E}$ to $30^{\circ} \mathrm{S}$ and $35^{\circ} \mathrm{E}$. During the cruise, three distinct fractions of the bacterioplankton viz. total count, total direct viable and retrievable counts were simultaneously enumerated in these waters. In the stations south of the convergent region designated as section I the population ranged within $10^{8-9} \mathrm{~L}^{-1}$ whereas in the north of the region designated as section II they were one order higher and ranged from $10^{9-10} \mathrm{~L}^{-1}$. The percentage of viability in the region was high corresponding to the generally high chlorophyll and primary productivity encountered in the eastern Aghulas bank. The study substantiates the hypothesis that in the Antarctic, not only the bacterial standing stock but also the active population of bacterioplankton (ca. $50 \%$ ) are almost equal in abundance to those in the other oceanic or coastal regions. The viable fraction forms a hitherto unreported significant component of these waters. (C) 2001 Ifremer/CNRS/IRD/Éditions scientifiques et médicales Elsevier SAS
\end{abstract}

Résumé - Viabilité des bactéries antarctiques dans le secteur indien. Lors de la $13^{\mathrm{e}}$ expédition antarctique indienne, nous avons examiné les populations bactériennes le long d'une section s'étendant de $70^{\circ} \mathrm{S}$ et de $18^{\circ} \mathrm{E}$ à $30^{\circ} \mathrm{S}$ et $35^{\circ} \mathrm{E}$. Trois fractions du bactérioplancton ont été dénombrées : la population totale, la population viable et le nombre de colonies. Au sud de la convergence (section I), les concentrations sont comprises entre $10^{8}$ et $10^{9}$ cellules par litre alors qu'au nord (section II), elles se situent entre $10^{9}-10^{10}$. Le pourcentage de viabilité est élevé dans cette dernière zone, également riche en chlorophylle et en production primaire (banc des Aiguilles). Cette étude confirme que les concentrations bactériennes et leur viabilité sont équivalentes dans l'océan Austral à ce qu'elles sont dans d'autres régions océaniques ou côtières de l'océan mondial. La partie viable représente une fraction significative, ce qui n'avait pas encore été mis en évidence. (C) 2001 Ifremer/CNRS/IRD/Éditions scientifiques et médicales Elsevier SAS

\section{bacteria / viability / Antarctic ocean / Indian side}

bactérie / viabilité / océan Antarctique / secteur indien

\section{INTRODUCTION}

The study of Antarctic microbiology dates back to the sixties and the expedition to the continent from the Indian side was initiated for the first time in 1982. Our endeavours to understand the Antarctic microbial ecology began with the work of Matondkar and Gomes (1983) and

* Correspondence and reprints.

E-mail address: loka@csnio.ren.nic.in (P.A. Loka Bharathi). subsequently with Matondkar (1986). Shivaji (1987) and Ramaiah (1995). These studies have been restricted to enumeration and taxonomy of aerobic bacteria. It has been shown that in the Antarctic, despite low water temperatures, bacteria play an important role in the energy transfer within the southern oceanic ecosystem Karl 1993: Delille 1996: Vincent 1988) Azam et al 1091 indicated that there is a paradigm shift in pelagic food web organization in Antarctic waters in that a large fraction of energy and material flow through the microbial loop. Total bacterial numbers give an appreciation of 
the contribution of bacteria to planktonic biomass, the retrievable or cultivable fraction is the one that could be used for comparison of data representing different times of the year or different areas Van_Es and_Meyer Reil 1982). However, the actual contribution to the activity of an ecosystem could come from a more important fraction viz. total viable count. The investigation substantiates the previous reports Kim. 1991: Simidu et al. 1986. $Z$ danowski and Donachie 1993 that in the Antarctic region, the bacterial standing stock is high. Also their viability is high and is nearly as much in the temperate oceanic or coastal region. In this study, the three different fractions, viz. total counts (TC), direct total viable counts (TVC), retrievable plate counts (RC) of the bacterial assemblages of sea waters from the Indian ocean side of the Antarctic is being reported for the first time.

\section{MATERIALS AND METHODS}

During the 13th Antarctic expedition (December 1993-March 1994), ten oceanographic stations were sampled along the cruise track from Dakshin Gangotri (Indian Base Camp) to Durban Port (fgure - $)$ for microbiological analysis. Seawater was collected from depths of 5, 50 and $100 \mathrm{~m}$ using a ZoBell's sampler. Stations 1-5 located south of $40^{\circ} \mathrm{S}$ latitude have been grouped together under section I as southern oceanic group and the rest under the northern section II for comparison.

The total counts (TC) were estimated by the AODC method (Hobbie et al. 1977). Total direct viable counts (TVC) were carried out as outlined by Kogure et al 1984). The tubes were incubated under low ambient temperatures of $8-12{ }^{\circ} \mathrm{C}$. For retrievable counts (RC), colonyforming units (CFU) were counted on ZoBell's medium by spread-plating. The plates were incubated at $8-10{ }^{\circ} \mathrm{C}$ for 10-20 d till the numbers of colonies were constant.

\section{RESULTS AND DISCUSSION}

The study of the bacterial distribution along the cruise track (figure ) showed generally increasing trend from stations 1 to 10 with the exception of station 2. Although there was an increase in bacterial number, it was not significantly different (foure 2). In section I, the TC ranged from $4.47-20.08 \times 10^{8} \mathrm{~L}^{-1}$. The total bacteria in the present study were one order higher than that reported in the Austral ocean by Gibson et al. (1990). These values are closer

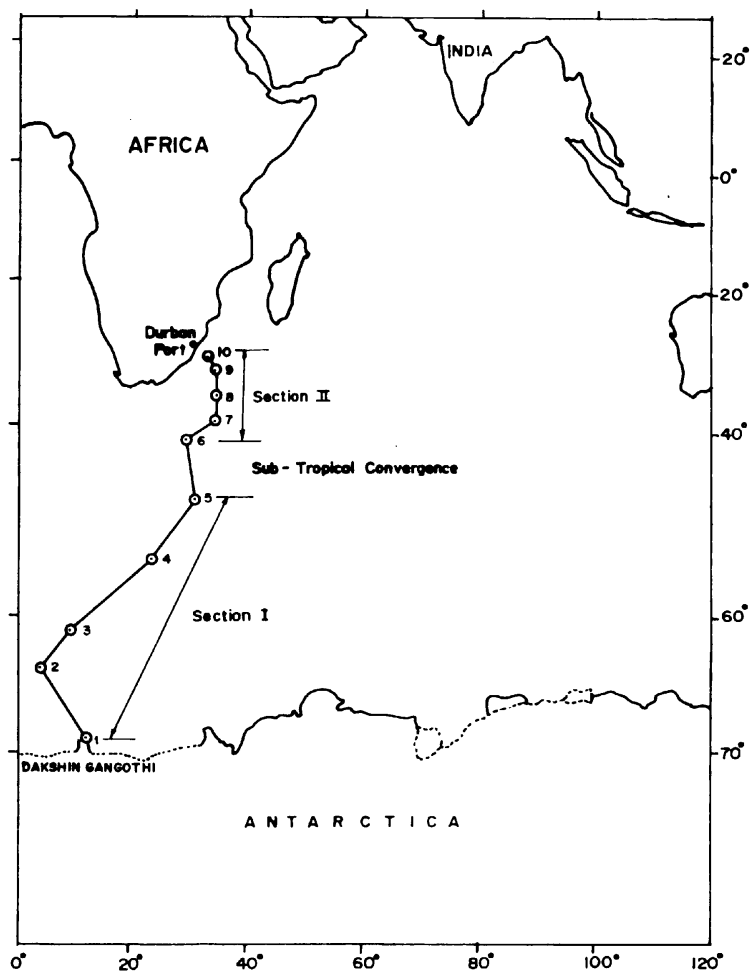

Figure 1. Sampling stations along the cruise track from Dakshin Gangotri (Indian Base Camp) to Durban Port.

to the abundance reported by Delille (1995) in the Antarctic neritic water. Bruni et al (1992) and Acosta Pomar et al_(1993) reported values for the Ross sea in the same range as in our studies. The variation in TC in section II was one to two orders higher than section I (Ggure 2). The average of the total bacterial load at $5 \mathrm{~m}$ depth was $1.36 \times 10^{9} \mathrm{~L}^{-1}$ in the Antarctic sea. Between the stations in the north and south of $40^{\circ} \mathrm{S}$, the northern ones (section I) had 6.6 times the populations in the south. Previous studies on chlorophyll, primary productivity and zooplankton estimation suggests that the region south of Antarctic convergence $\left(46-53^{\circ} \mathrm{S}\right)$ to be more productive than other regions Verlencar et al 1990; Froneman and Perissihotto, 1996: Curran et al. 1998; Froneman et al. 1998). However, in the present study, few stations north of the subtropical convergence $\left(\sim 40^{\circ} \mathrm{S}\right)$ harboured higher numbers. This higher abundance in bacterial counts at stations 9 and 10 than in the southern stations may be due to their proximity to Aghulas bank. This region is characterized by high levels of primary production due to intense shelf edge upwelling (Probyn et al_ 1994_ 1995) and bacteria utilize $10-50 \%$ of net productivity of the dis 


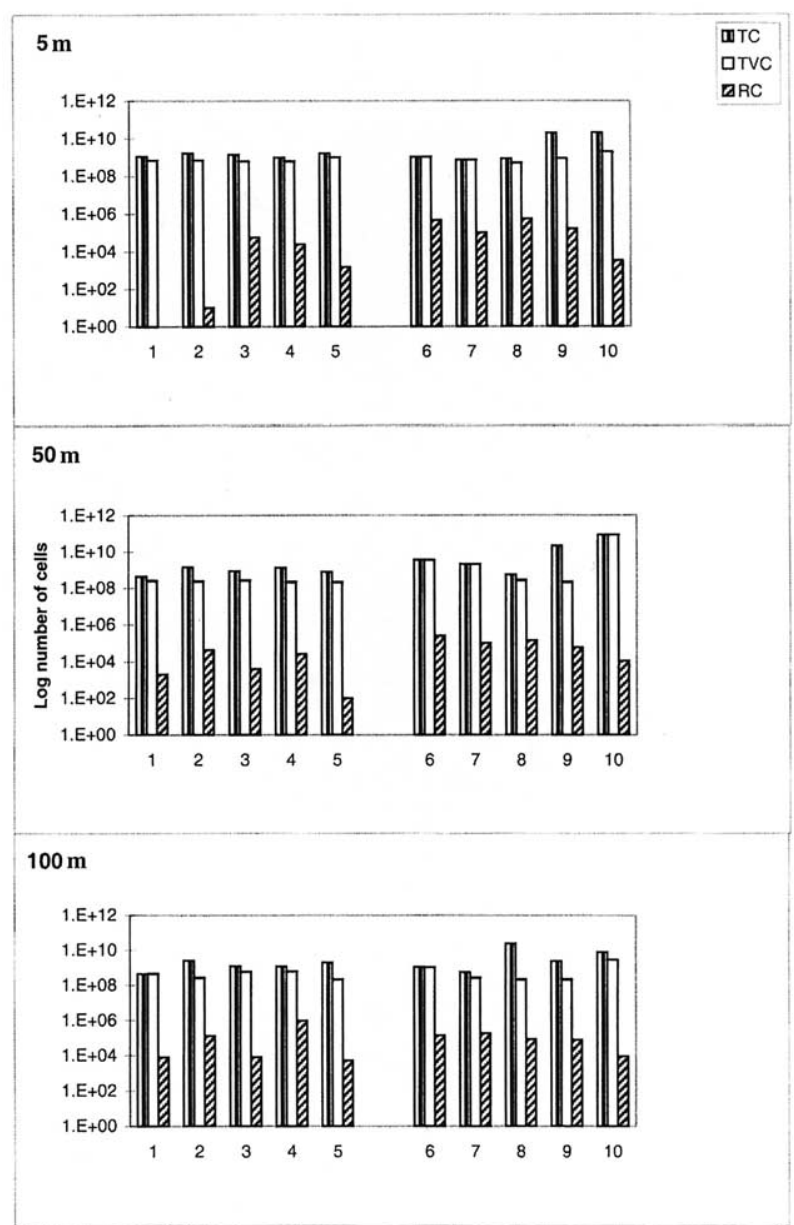

Figure 2. Abundance of the three fractions of bacteria (total counts: TC, total viable counts: TVC and retrievable counts: RC) at different depths in sections I and II.

solved organic matter Euhrman and_Azam_ 1980. Besides, eastern Aghulas bank is characterized by shallower, often more intense thermocline during the summer stratified period. Perhaps all these factors were responsible for a higher bacterial stock. The unusually high numbers observed at 5 and $50 \mathrm{~m}$ depths at station 9 , and at $100 \mathrm{~m}$ at station 8 may be due to either the patchy distribution of bacteria or effect of algal blooms Bouvy and Delille, 1988). The TVC and RC are also of great assistance in understanding the influence of active fraction density. The TVC was two orders higher in magnitude than the RC. There was a good correlation between TC and TVC $(r=0.9088, n=30, P>0.001)$ suggesting that the latter was responsible for $82 \%$ of the variation in TC. Hence, the possibility of including a large virus-like particle Sommeruga et al. 1995 in the counts is greatly reduced. There was significant variation in the distribution of $\mathrm{RC}$ in sections I and II at 5 and $50 \mathrm{~m}(P>0.05)$. The bacterial viability observed in both sections irrespective of depth was high and almost equal to that in the euphotic zone (Bianchi_and_Gidiano, 1996) with section II showing higher viability. Interestingly, this high viability was more marked in the marine waters than in the Antarctic lacustrine waters (Loka Bharathi_et_al, 1999) Kogure_et_al (1986) could correlate the viable numbers to heterotrophic activity in the water column suggesting high mineralisation potential in these waters. Dufour et al (1990) have suggested that in more productive systems the abundance and proportion of active bacteria is high. The high viability observed in our study corroborated with the reported high surface productivity rate of $4-29 \mathrm{~g} \mathrm{C} \cdot \mathrm{m}^{-2} \cdot \mathrm{h}^{-1}$ (VerLencar and Dhargalkar, 1992. (table ).

Thus our studies indicate that in the Indian side of Antarctic, despite low water temperature, bacterial numbers are high and almost equal to that encountered in the other oceanic or coastal realms. The high viability $(>50 \%$ ) of the bacterial assemblage in the southern most areas of the Antarctic zone suggests that it forms an important component of the bacterioplankton and could contribute significantly to the cycling of nutrients.

\section{Acknowledgements}

We would like to express our sincere thanks to Prof. F. Azam, Scripps Institute of Oceanography for his valuable suggestions. The

Table I. Variations in primary productivity, chlorophyll in sections I and II of the Antarctic sea from the Indian side.

\begin{tabular}{llll}
\hline Location & Chlorophyll & Primary productivity & Reference \\
\hline Section I $\left(48-70^{\circ} \mathrm{S}\right)$ & $7.5-64.4 \mathrm{mg} \cdot \mathrm{m}^{-2}$ & $0.5-7 \mathrm{mg} \mathrm{C} \cdot \mathrm{m}^{-2} \cdot \mathrm{h}^{-1}$ & Verlencar and Dhargalkar, 1992 \\
Section I (south of $\left.67^{\circ} \mathrm{S}\right)$ & $0.45-4.03 \mathrm{mg} \cdot \mathrm{m}^{-3}$ & $0.4-3.33 \mathrm{mg} \mathrm{C} \cdot \mathrm{m}^{-3} \cdot \mathrm{h}^{-1}$ & Verlencar et al., 1990 \\
Section II oceanic & $8.0-23.6 \mathrm{mg} \cdot \mathrm{m}^{-2}$ & $4-29 \mathrm{mg} \mathrm{C} \cdot \mathrm{m}^{-2} \cdot \mathrm{h}^{-1}$ & Verlencar and Dhargalkar, 1992 \\
Section II coastal (off SE Africa) & $22.5-88.2 \mathrm{mg} \cdot \mathrm{m}^{-3}$ & $85.2-1372.8 \mathrm{mg} \mathrm{C} \cdot \mathrm{m}^{-2} \cdot \mathrm{h}^{-1}$ & Probyn et al., 1995 \\
\hline
\end{tabular}


author PAL records her thankfulness to the Department of Ocean Development for the opportunity to participate in the 13th Indian Antarctic Expedition. The help rendered during sampling by the expedition leader and team members is duly acknowledged. The authors are thankful to the anonymous referees for their valuable suggestions. This is NIO contribution No. 3717.

\section{REFERENCES}

Acosta Pomar, M.L.C., Bruni, V., Maugeri, T.L., 1993. Picoplankton biomass in the Ross Sea (Antarctica). Polar Biol. 13, 1-6.

Azam, F., Smith, D.C., Hollibaugh, J.T., 1991. The role of microbial loop in Antartic pelagic ecosystem. Polar Res. 10, 239-243.

Bianchi, A., Giuliano, L., 1996. Enumeration of viable bacteria in marine pelagic environment. Appl. Environ. Microbiol. 62, 174-177.

Bouvy, M., Delille, D., 1988. Spatial and temporal variations in Antarctic and subantarctic bacterioplankton. Neth. J. Sea Res. 22, 139-147.

Bruni, V., Acosta Pomar, M.L.C., Maugeri, T.L., Crisafi, E., La Ferla, R., Zaccone, R., 1992. Further observations on the microbial populations in Terra Nova Bay. Natl. Sci. Co. Antarctic Ocean Camp, 1989-1990.

Curran, M.A.J., Jones, G.B., Burton, H., 1998. Spatial distribution of dimethylsulfide and dimethylsulfoniopropionate in the Australasian sector of the Southern Ocean. J. Geophys. Res. D Atmos. 103, 677-689.

Delille, D., 1995. Seasonal changes in phytoplankton and bacterioplankton distribution at the ice-water interface in the Antarctic neritic area. Mar. Ecol. Prog. Ser. 123, 225-233.

Delille, D., 1996. Biodiversity and function of bacteria in the Southern Ocean. Biodiv. Conserv. 5, 1505-1523.

Dufour, P., Torretan, J.P., Colon, M., 1990. Advantages of distinguishing the active fraction in bacterioplankton assemblages. Hydrobiology 207, 295-301.

Froneman, P.W., Perissinotto, R., 1996. Structure and grazing of the microzooplankton communities of the subtropical convergence and a warm-core eddy in the Atlantic sector of the Southern Ocean. Mar. Ecol. Prog. Ser. 135, 237-245.

Froneman, P.W., Pakhomov, E.A., Meaton, V., 1998. Surface distribution of microphytoplankton of the south-west Indian Ocean along a repeat transect between Cape Town and the Prince Edward Islands. S. Afr. J. Sci. 94, 124-129.

Fuhrman, J.A., Azam, F., 1980. Bacterioplankton secondary production estimates for coastal waters of British Columbia, Antarctica and California. Appl. Environ. Microbiol. 39, 1085-1095.

Gibson, J.A.E., Garrick, R.C., Burton, H.R., 1990. Seasonal fluctuation of bacterial numbers near the Antarctic continent. In: Hoshiai, T. (Ed.). Proc. Nipr. Symp. Polar Biol. 3, 16-22.

Hobbie, J.E., Daley, R., Jasper, S., 1977. Use of nucleopore filters for counting bacteria by fluorescence microscopy. Appl. Environ. Microbiol. 33, 1225-1228.

Karl, D.M., 1993. Microbial processes in the southern oceans. In: Imre Friedmann, E. (Ed.), Antarctic Microbiology. Wiley-Liss, pp. 1-63.
Kim, S.J., 1991. Bacterial number, heterotrophy and extracellular enzyme activity in the Bransfield straight, Antarctica. Second International Symposium on Antarctic Science 2, 9-16.

Kogure, K., Simidu, U., Taga, N., 1984. An improved direct viable count method for aquatic bacteria. Arch. Hydrobiol. 102, 117-122.

Kogure, K., Fukami, K., Simudu, U., Taga, N., 1986. Abundance and production of bacterioplankton in the Antarctic. Mem. Nat. Inst. Pol. Res., Special Iss. 40, 412-422.

Loka Bharathi, P.A., Shanta Nair, De Souza, M.J., Chandramohan, D., 1999. Truce with oxygen - Anaerobiosis outcompetes aerobiosis in the Antarctic lacustrine bacteria. Curr. Sci. 76, 1585-1587.

Matondkar, S.G.P., 1986. Microbiological studies in the Schirmacher Oasis, Antarctica: effect of temperature on bacterial population, Scientific Report of Third Indian Expedition to Antarctica. Technical Publication 3, New Delhi India, pp. 133-147.

Matondkar, S.G.P., Gomes, H.R., 1983. Biological studies on the ice shelf and in a freshwater lake at Princes Astrid Coast. Drowning Maud Land, Antarctica, Scientific Report of first Indian Expedition to Antarctica. Technical Publication 1, New Delhi India, pp. 186-190.

Probyn, T.A., Mitchell-Innes, B.A., Hutchings, C., Carter, R.A., 1994. A review of primary production and related processes on the Agulhas Bank. S. Afr. J. Sci. 90, 166-174.

Probyn, T.A., Mitchell-Innes, B.A., Searson, S., 1995. Primary productivity and nitrogen uptake in the subsurface chlorophyll maximum on the Eastern Agulhas Bank. Cont. Shelf Res. 15, 1903-1920.

Ramaiah, N., 1995. Summer abundance and activities of bacteria in the fresh water lakes of Schirmacher Oasis, Antarctica. Polar Biol. 15, 547-553.

Shivaji, S., 1987. A preliminary note on bacteria and yeasts of Antarctica, Scientific Report of the fourth Indian Scientific Expedition to Antarctica. Technical Publication 4 New Delhi, India, pp. 155-158.

Simidu, U., Kogure, K., Fukami, K., Imada, C., 1986. Heterotrophic Bacterial flora of the Antarctic Ocean. Proceedings of the Seventh Symposium on. Polar Biol. 40, 405-412.

Sommeruga, R., Krossbacher, M., Salvenmoser, W., Catalan, J., Psenner, R., 1995. Presence of large virus-like particle in a eutrophic reservoir. Aquat. Microb. Ecol. 9, 305-308.

Van Es, F.B., Meyer Reil, L.A., 1982. Biomass and metabolic activity of heterotrophic marine bacteria. In: Marshall, K.C. (Ed.), Advances in Microbial Ecology. Plenum Publishing Corp., New York, USA, pp. 11-170.

Verlencar, X.N., Dhargalkar, V.K., 1992. Primary productivity and nutrients in the Indian Sector of the Southern Ocean, Ind. J. Mar. Sci. 21, 6-12.

Verlencar, X.N., Somasunder, K., Qasim, S.Z., 1990. Regeneration of nutrients and biological productivity in Antarctic waters. Mar. Ecol. Prog. Ser. 61, 41-59.

Vincent, W.F., 1988. Microbial Ecosystems of Antarctica. Cambridge University Press, London.

Zdanowski, M.K., Donachie, S.P., 1993. Bacteria in the sea ice zone between Elephant Island and South Orkneys during the Polish Sea ice zone Expedition. Polar Biol. 13, 245-254. 